\title{
IMPACT OF BOARD CHARACTERISTICS ON FIRM PERFORMANCE: DYNAMIC PANEL EVIDENCE OF THE INSURANCE INDUSTRY IN THE REPUBLIC OF NORTH MACEDONIA
}

\author{
Tanja Kamenjarska \\ Faculty of Economics - Skopje, Ss. Cyril and Methodius University \\ kamenjarska@eccf.ukim.edu.mk \\ Igor Ivanovski \\ Faculty of Economics - Skopje, Ss. Cyril and Methodius University \\ ivanovski@eccf.ukim.edu.mk
}

\begin{abstract}
Corporate governance is a crucial mechanism for the organizations' actions to maintain market successful adequate and targeted policies and long-term strategies that ensure the maximization of shareholders' benefits. The board of directors is appointed by organizations' shareholders and its main role is to be responsible and accountable and to ensure enforcement of the top management acts concerning the fulfillment of the shareholder's interests. For this to be achieved, it is important for the board to be efficient, effective, and focused on protecting the organization and shareholder's interests. Good corporate governance and more specifically, board characteristics play a central role in companies' management, coordination, and control mechanisms. The paper analyses various theoretical and empirical findings regarding the prominence of various board characteristics within companies and particularly evaluates the impact of board characteristics on the financial performance of listed companies in the insurance industry in the Republic of North Macedonia. The financial ratio $R O A$ is used as a proxy and as a variable for firm performance while the board experience, CEO duality, board size, board composition, and gender diversity are set to be as independent variables. Based on the variables related to board characteristics, hypotheses are developed and their impact upon firm performance is examined with the use of Generalized Methods of Moments (GMM), a pairwise correlation matrix, as well as with multicollinearity VIF test. In that direction, this paper aims to determine the level of effectiveness of current governance mechanisms and based on the results, propose measures and actions for successfully handling agency costs while maximizing governance capability and performance in the insurance sector in the Republic of North Macedonia.
\end{abstract}

Keywords: Insurance industry, GMM, Financial performance, Corporate governance, Republic of North Macedonia.

JEL classification: $G 22, G 30$

\section{INTRODUCTION}

In recent years, numerous attempts have been made in direction of determining the impact of the level of efficiency and effectiveness of the board of directors and its characteristics on firms' market value and performance. Such analyses have been subject of scientific studies whereas the findings gained a lot of attention amongst academicians and the business sector. Pertinent corporate governance is a crucial mechanism for the organization to maintain adequate and targeted policies and long-term strategies that ensure the maximization of shareholders' benefits. The board of directors is elected by organizations' shareholders and its main role is to be responsible and ensure that the top management acts upon maximization of 
shareholder's interests. For this to be achieved, the board needs to be efficient and effectively focused on protecting the shareholder's interests. Many studies and corporate practices suggest that larger board sizes may increase the capacity of additional experienced members who can disseminate and engage their knowledge and skills in the company. On the contrary, the cost of maintaining this structure could increase leading to harder and complex coordination between the professionals. However, the size of the board appears as one parameter in determining the management structure and its role in defining, developing, and upgrading the company's organizational culture and its market success. The corporate practice imposes vast examples of market failures as well as benchmarks concerning board members' education, professionalization, permanent education, and gender diversity. The role of the HCM is increasingly becoming important, while the competitive pressure is rising. These particular aspects are a matter of concern of the paper which is divided into several sections. First, we provide an overview of the relevant literature as a basis for developing hypotheses. Next, we define a statistical model alongside with the methods used for data collection in the insurance industry in the Republic of North Macedonia. We then proceed to the presentation of the results from the pairwise correlations, GMM tests, and the multicollinearity VIF test. Finally, the findings allow us to attempt to provide preliminary recommendations that companies may consider in establishing a consistent structure of the board of directors, leading to efficient management, increased financial performance, and higher firm value. The objectives of the study are set to identify the board characteristics' that have a significant impact on the financial performance, identify the relationship between these factors and the financial performance of the company, and as a result provide initial actions for the companies to consider in direction of enhancing the market share and value of the company.

\section{LITERATURE OVERVIEW AND HYPOTHESES DEVELOPMENT}

Good corporate governance strives to create long term and sustainable value and to provide a system of integrity-based management practices and principles that are of interest to the stakeholders. By following the concept of shareholders' responsibility, companies become resilient and build a strong reputation which increases internal reliability, cohesion, and integrity. To improve overall financial performance and consumer trust and confidence at the market, good governance practices are used to create and use the investment opportunities and to reduce overall risk for investors, resulting in recognizable and sustainable organizational culture and higher financial capacity. They may also be associated with reduced risk of fraud, corruption, unethical behavior, and actions as well. Many empirical studies investigate the correlation between good corporate governance and a firm's operational performance, the cost of the capital, and the reduced inherent risks. It is noticeable that the better the company's structure and corporate governance practices the greater the probability that the assets of the company are used in the interest of its shareholders and are not misused by managers. Therefore, besides the financial and accounting indicators, corporate governance has become one of the most significant criteria for the investor's investment decisions. The major responsibility of the board of directors is to appoint a qualified and competent CEO who will successfully lead and monitor the work of the management structure and check for its compliance with company standards and strategy. Board members must provide consistency in the business operations by interminably encouraging effective decision making and reinforcing sustainable firm values. The ultimate goal of corporate governance is unraveling the issue regarding agency problem which originally derives from the conflict of interest between principals (shareholders) and agents, namely managers (Liu and Fong, 2010). Concerning this issue, a wide variety of studies have been conducted. For instance, Vafeas (1999) investigates the impact of board meeting frequency on corporate governance and 
ownership characteristics for 307 firms over the period of 1990 to 1994 . The author suggests that the yearly meetings of the board are inversely correlated with firm value. These results are supported by Hanh et al. (2018) who use a sample of 94 firms listed on the Ho Chi Minh Stock Exchange in Vietnam from 2013 to 2015. On the contrary, Al-Daoud et al. (2016) examine firms listed on the Amman Stock Exchange from industry and service sectors for the 20092013 period with the use of the dynamic panel technique of Generalized Method of Moments (GMM). They find a positive relationship between the frequency of corporate board meetings and firm performance.

\subsection{Board size}

When analyzing the factor of the board size, the empirical studies report inconclusive and contradictory results. The larger board can lead to an increased level of competence, more knowledge-based structure and experience brought in the company, making it easier to apply the professional diversity, critical thinking as well as the brainstorming techniques which could improve the quality and accuracy of group thinking. It is noteworthy that boards with more diverse members can continuously re-examine facts, boost the innovation capacity, remain objective, and as a result solve difficult problems, particularly within crisis management. In that manner, numerous authors suggest that there is a positive relationship between board size and financial performance (Dowen, 1995; Dalton et al. 1999; Adam \& Mehran, 2003; Coles et al. 2008). Coles et al. (2008) suggest that this implies only for larger and firms with complex structure, often related to the trans-national corporations with a high part of the international operations. On the contrary, larger boards can immanently cause higher cost, and more importantly, if a lack of coherence and openness exists within the group it can lead to miscommunication and poor coordination issues, which further can develop into structural distortion. In such terms, many studies show an inverse relationship between board size and firm value (Lipton \& Lorsch, 1992; Yermack, 1996; Loderer and Peyer, 2002; Lasfer, 2004; Yoshikawa and Phan, 2004; Hardwick et al. 2004; Mak and Kusnadi, 2005, Pablo de Andres et al., 2005; Harris and Raviv, 2008; Cheng, 2008). In this regard, we can define the following hypothesis, as:

\section{H1: There is a significant relationship between firm performance and board size.}

\subsection{Board independence (composition)}

According to Carlsson (2001), the central issue of the Corporate Governance Code is the importance of an independent and competent board. Even though some researchers have not determined a statistically significant relationship between board independence and financial performance (Hermalin and Weisbach, 1991; Barnhart and Rosenstein, 1994; Mehran, 1995; Bathala and Rao, 1995; Klein, 1998), it is very common for this correlation to appear negative (Agrawal and Knoeber, 1996; Bhagat and Black, 2000; Shukeri et al., 2012). Dahya and McConnell (2007) for example, find diametrically opposing results, meaning that there is a statistically significant and positive relationship between the board's composition and firm performance. Results from other studies support this view (Rosenstein and Wyatt, 1990; Prevost et al., 2002; Limpaphayom \& Sukchareonsin, 2003; Hasnah, 2009; Awan, 2012). Also, we should note the difference and yet the inter-connectivity between the boards' independence and competence, as the formality of the independence is linked to the substantial issue of the competence. Furthermore, we propose the second hypothesis as with the element of board composition, as in an attempt for merging the boards' independence and competence:

H2: There is a significant relationship between Firm performance and Board composition. 


\subsection{Gender diversity}

By following the concept of board diversity, it is believed that companies overall governance will improve (Daily, Certo \& Dalton, 1999; Singh \& Vinicombe, 2004) and by adding multiple female members in the board it will help the company to gain a better understanding of the customer needs (Liu et al., 2013) while promoting social inclusion. Also, heterogenous board structure in the means of gender, ethnicity, occupation, will bring new ideas, creativity, and innovation within the organization and make the decision-making process easier with the use of greater problem-solving capabilities and critical and strategic thinking.

As the number of female members in the board increase, the greater the opportunities for innovation and presenting various standpoints, new perspectives and opinions can occur and be practiced, as noted in several kinds of research (Miller and Triana, 2009; Torchia et al., 2011; Lazzaretti et al., 2013; Torchia, Calabrò and Michèle, 2015). Numerous studies find a positive link between the number of women in the board and firm performance (Bonn, 2004; Smith et al., 2006; Campbell and Mínguez-Vera, 2008; Liu et al., 2013; Lückerath-Rovers, 2013; Isidro and Sobral, 2014; Low et al., 2015). However, other studies show an insignificant relationship between the number of women directors and firm performance (Ding and Charoenwong, 2004; Farrell and Hersch, 2005; Skimkins and Simpson,2010; Dobbin and Jung, 2011; Chapple and Humphrey, 2013; Gordini and Rancati, 2017). Negative impact has been reported in the study of Pathan and Faff (2013) in which they investigate the relationship between gender diversity and bank performance. In that manner, there is a possibility for this relationship to appear negative (Adams and Ferreira, 2009; Mínguez-Vera and Martin, 2011). Based on the presented relevant literature, we propose the following third hypotheses:

\section{$H_{3}:$ There is a significant relationship between firm performance and gender diversity.}

\subsection{CEO duality}

Results from a variety of studies prove that the separation of the chairman from the executive manager is insignificant (Daily \& Dalton, 1997; Dalton et al., 1998; Valenti et al., 2011), meaning that CEO duality does not make difference in the efficiency of the board and firm performance. For instance, Chia-Wei Chen et al. (2008) collect data for firms in the S\&P 1500 index, which consists the S\&P 500, the S\&P 400 mid-cap, and the S\&P 600 over the period of 1999 to 2003. By using OLS regression, applied Heckman's self-selection model to control for endogeneity, and use fixed effect model to control for impacts of non-observable firm variables, no significant relationship was identified between CEO duality and firm performance. Oppositely, this separation has proved to have a positive impact on firm performance and has been reported by multiple scholars (Rechner and Dalton, 1991; Greenbury, 1995; Higgs, 2003; Peng et al., 2007). These findings have been supported by Mohammadi et al. (2015) who suggest that the positive effect varies across environmental dimensions of munificence, dynamism, and complexity. Some studies show that CEO duality has a negative impact on firm performance, consistent with the agency theory (Dogan et al., 2013; Shiu-Wan Huang et al., 2012). In this relation, we set the following hypothesis:

\section{$\mathrm{H}_{4}$ : There is a significant relationship between firm performance and CEO duality.}

\subsection{Board experience}

Undoubtfully, providing expert advice helps companies to develop effective management principles and practices to ensure the permanence of the business. The presence of highly qualified and experienced board members will result in a combination of expertise which can stimulate a thoughtful exchange of suggestions within a company (Carpenter \& Westphal, 
2000). For instance, Berger et al. (2014) use data from the banking sector in Germany where they discover that portfolio risk declines when the board consists of more executives who have obtained Ph.D. degrees. Interestingly, Haniffa and Cooke (2002) find a positive relationship between general business and accounting education of board directors and disclosure of information that demonstrates the accountability and credibility of the top management team. Therefore, multiple studies have obtained statistically significant and positive results regarding the relationship between board members' competencies and firm performance (Hunt, 2000; Ljungquist, 2007). It is important for board members to obtain a variety of skills and demonstrate divergent standpoints concerning the decision-making process in an organization (Biggins, 1999). Hau and Thum (2010) conduct a study of Germany's largest 29 banks and investigate the competencies of 593 supervisory board members. The obtained results show that the lack of financial experience of the board members is directly correlated with the bank losses during the 2007/2008 financial crisis. Possessing and executing board members' higher formal education, professional experience, and empirical-based skills are integrated within the last hypothesis as:

\section{H5: There is a positive relationship between firm performance and board experience}

\section{METHODOLOGY}

\subsection{Sample selection and variable definitions}

The sample consists of 13 insurance companies that operated in the Republic of North Macedonia from 2012 to 2018, both for the non-life and the life sector, which counted as 11 non-life companies and 4 life companies. Due to the incomplete data and lack of information available, frequent board changes, and corporate ownership, Triglav Life Insurance, Halk Insurance (previously Nova Insurance) and Grawe Non-Life Insurance (previously Eurosig Insurance) were excluded from the sample. Data is extracted from the public disclosed companies' annual financial reports, Insurance Supervisory Agency Annual reports, and the National Bank of the Republic of North Macedonia databases.

Over the years, researchers have developed various approaches and applied a wide range of methodologies to assess the impact of profitability determinants in the insurance industry. We have identified that the current profitability depends on its past realizations which is also strongly backed up by empirical and theoretical evidence. For this purpose, we apply the use of dynamic panel analysis. Unlike static panel data models, the system GMM estimator allows us to resolve the issue regarding the serial correlation, heteroskedasticity, and endogeneity of variables (Leitao, 2010). To achieve this, we have applied the methodology that Arellano and Bond (1991) proposed, and later Blundell and Bond (1998, 2000) improved. First, the use of pairwise correlation permits us to identify if multicollinearity between variables exists. Next, we apply the Hansen test to check the validity of the over-identifying restrictions. If the null hypothesis is rejected, the instruments in the model are invalid. To check if there is a first-order (m1) and second-order (m2) serial correlation in the residuals, we use Arellano and Bond test. If the null hypothesis is accepted, we can conclude the model is consistent. 


\begin{tabular}{|c|c|c|c|}
\hline Variables & Abbreviation & Measurement & Expected sign \\
\hline \multicolumn{4}{|l|}{ Dependent variable } \\
\hline Return on assets & ROA & $\begin{array}{r}\text { The ratio between } \\
\text { EBIT and the firm's } \\
\text { total assets }\end{array}$ & \\
\hline \multicolumn{4}{|c|}{ Independent variables } \\
\hline Board experience & BRD_EXP & $\begin{array}{r}\text { Number of members } \\
\text { with financial or } \\
\text { accounting experience }\end{array}$ & + \\
\hline CEO duality & CEO_DUAL & $\begin{array}{r}\text { Dummy variable, ' } 1 \text { ' } \\
\text { for firms with the } \\
\text { CEO as Chair, ' } 0 \text { ' if } \\
\text { positions are separated }\end{array}$ & $+/-$ \\
\hline Board size & BRD_SIZE & $\begin{array}{r}\text { Number of directors' } \\
\text { in board }\end{array}$ & $+/-$ \\
\hline Board composition & BRD_COMP & $\begin{array}{r}\text { Number of } \\
\text { independent directors } \\
\text { to the total number of } \\
\text { directors' in board }\end{array}$ & $+/-$ \\
\hline Gender diversity & GEN_DIV & $\begin{array}{r}\text { Percentage of women } \\
\text { on the board }\end{array}$ & $+/-$ \\
\hline
\end{tabular}

Source: Authors calculation

Table 1 presents an overview of both dependent and independent variables along with their abbreviation, measurement, and expected sign. Return on assets (ROA) is used as a proxy to measure the firm's financial performance and is set to be a dependent variable. It is calculated as a ratio between earnings before interest and tax and the firm's total assets. In addition, Board experience, CEO duality, Board size, Board composition, and Gender diversity are independent variables.

\subsection{Pairwise correlation matrix}

In the direction of determining the existence of multicollinearity, a pairwise correlation is estimated between variables (Table 2). The low correlation coefficients or more specifically, the peak value of coefficients below 0.7 (Gujarati, 1995) imply absence of multicollinearity. In this case, the coefficient values are in desirable range and we can conclude that no multicollinearity exists between the variables. 
Table 2. Pairwise correlation matrix

\begin{tabular}{lllllll}
\hline & ROA & BRD_EXP & CEO_DUAL & BRD_SIZE & BRD_COMP & GEN_DIV \\
\hline ROA & 1.0000 & & & & & \\
\hline BRD_EXP & 0.6329 & 1.0000 & & & & \\
\hline CEO_DUAL & 0.0502 & 0.4821 & 1.0000 & & & \\
\hline BRD_SIZE & 0.0564 & 0.2107 & 0.3234 & 1.0000 & & \\
\hline BRD_COMP & 0.3419 & 0.1281 & -0.0146 & 0.5458 & 1.0000 & 1.0000 \\
\hline GEN_DIV & 0.2876 & 0.5885 & 0.3005 & 0.4958 & -0.0403 & \\
\hline
\end{tabular}

Source: Authors calculation

\subsection{Empirical specification}

To determine the impact of boards' characteristics on firm performance of the insurance companies in the Republic of North Macedonia, and since the current profitability depends on its past realizations, we use dynamic panel analysis, or more specifically, two-step Generalized Methods of Moments (GMM) estimator developed by Arellano and Bond (1991) and Blundell and Bond (1998):

$$
R O A_{i t}=\alpha+\delta R O A_{i, t-1}+\sum_{f=1}^{F} \beta_{f} X_{i t}^{f}+\varepsilon_{i t}, \varepsilon_{i t}=v_{i t}+u_{i t}
$$

where $R O A_{i t}$ is the profitability of firm $i$ at time $t$, with $i=1, \ldots, N$, and $t=1, \ldots, T, \alpha$ is a constant term, $\delta$ is the speed of adjustment to equilibrium, $R O A_{i, t-1}$ is the firm's lagged profitability for one-period, $\beta_{f}$ represent vectors of coefficients to be estimated, $X_{i t}^{f}$ is a set of explanatory variables, $\varepsilon_{i t}$ is error term, $v_{i t}$ firm-specific time-invariant effect and $u_{i t}$ the idiosyncratic error.

\section{RESULTS AND FINDINGS}

The results of the generalized methods of moments (GMM) panel estimator of various determinants of profitability are presented in Table 3 . The Arellano-Bond test for AR(1) in first differences has a value of 0.128 and the Arellano-Bond test for AR(2) in first differences 0.858 which shows an absence of second-order serial correlation in disturbances. Furthermore, the Hansen test shows a p-value of 0.584 which is greater than 5\% (0.05) and indicates that we can accept the null hypothesis, that is over-identifying restrictions are valid.

Table 3. Dynamic panel data estimation results

Dependent variable: $\mathrm{ROA}$

\begin{tabular}{lcc}
\hline Explanatory variables & $\begin{array}{c}\text { Coefficients } \\
\text { (Standard errors) }\end{array}$ & p-value \\
\hline Constant & -.08918 & 0.000 \\
& $(.0345585)$ & 0.012
\end{tabular}




\begin{tabular}{|c|c|c|}
\hline \multirow[t]{2}{*}{ BRD_EXP } & $.0445894 * * *$ & 0.000 \\
\hline & $(.0088761)$ & \\
\hline \multirow[t]{2}{*}{ CEO_DUAL } & .0350462 & 0.121 \\
\hline & $(.0235806)$ & \\
\hline \multirow[t]{2}{*}{ BRD_SIZE } & $-.0283626^{*}$ & 0.070 \\
\hline & $(.0133107)$ & \\
\hline \multirow[t]{2}{*}{ BRD_COMP } & $.0441751 * * *$ & 0.000 \\
\hline & $(.013186)$ & \\
\hline \multirow[t]{2}{*}{ GEN_DIV } & .0142028 & 0.246 \\
\hline & $(.0124453)$ & \\
\hline Number of observations & 78 & \\
\hline Number of instruments & 13 & \\
\hline Arellano-Bond test for AR (1) (p-value) & $\mathrm{z}=-1.52 \mathrm{PR}>\mathrm{z}=0.128$ & \\
\hline Arellano-Bond test for AR (2) (p-value) & $\mathrm{z}=0.18 \mathrm{PR}>\mathrm{z}=0.858$ & \\
\hline $\begin{array}{l}\text { Hansen test of overid. restrictions } \chi^{2}(3)= \\
1.94\end{array}$ & Prob $>\chi^{2}=0.584$ & \\
\hline
\end{tabular}

***statistically significant at $1 \%$ level, **statistically significant at $5 \%$ level, ${ }^{*}$ statistically significant at $10 \%$
level.

Notes: Companies included: Winner Life, Winner Non-Life, Uniqa Life, Uniqa Non-Life, Triglav Non-Life, Osiguritelna Polisa, Croatia Life, Croatia Non-Life, Euroins, Makedonija Insurance, Eurolink, Grawe Life, Sava.

\section{Source: Authors calculations}

The significant coefficient of the lagged profitability (L.ROA) at 5\% significance level proves that the dynamic model specification is appropriate for the research. The obtained results show a statistically significant and positive effect of the board experience, that is compatible to the findings of the vast relevant studies concluded (Carpenter and Westphal, 2000; Hunt, 2000; Haniffa and Cooke, 2002; Ljungquist, 2007; Berger et al., 2014). The importance of the board members' professional qualification based on formal education and professional expertise appears as crucial for the comprehensive understanding and managing the complex and in particular highly regulated insurance industry, especially when competitive pressure is rising. Furthermore, the statistically significant and positive effect of the board composition on the profitability, as determined at some studies (Rosenstein and Wyatt, 1990; Prevost et al., 2002; Limpaphayom \& Sukchareonsin, 2003; Hasnah, 2009; Awan, 2012), even though inconclusive at other studies, defines the importance of the management structure, understood in wider terms, that underlines the significance of the professionals and empirical knowledge based managers that would undertake adequate and market-orientated and sustainable policies and actions. Furthermore, evident significant and negative relationship between board size and financial performance of insurance companies, could be linked to the prevalent one-level management model within the Macedonian insurance companies and focus on medium-size boards. However, the negative correlation should be a matter of further analysis and in-depth focus for determining the alterations and attempting to achieve more conclusive and qualitative backed findings concerning the previous studies and findings (Lipton \& Lorsch, 1992; 
Yermack, 1996; Loderer and Peyer, 2002; Lasfer, 2004; Yoshikawa and Phan, 2004; Hardwick et al. 2004; Mak and Kusnadi, 2005, Pablo de Andres et al., 2005; Harris and Raviv, 2008; Cheng, 2008).

The obtained results according to which an insignificant relationship between CEO duality and financial performance was determined, are supported by numerous studies (Daily and Dalton, 1997; Dalton et al., 1998; Chia-Wei Chen et al. 2008; Valenti et al., 2011). The circumstances in which this variable take effect, are similar in regards to the insignificance of the gender diversity and firm's performance and are in congruence with a majority of existing research in means of insignificant link between the two variables (Ding and Charoenwong, 2004; Farrell and Hersch, 2005; Skimkins and Simpson, 2010; Dobbin and Jung, 2011; Chapple and Humphrey, 2013; Gordini and Rancati, 2017). Albeit the yielded insignificant impact of these variables on companies' financial performance, these correlations ought to encourage a focused scientific discourse and should be under further investigation and a matter of diligent analysis.

\subsection{Multi-collinearity VIF tests}

After successfully carrying out the GMM tests, the variance inflation factor (VIF) test is used to check if multicollinearity in the model exist. As the level of multicollinearity increases, the coefficients and the standard errors of the model become unsteady and unreliable. This problem appears when the VIF values are greater than 10. In this regard, VIF values for BRD_SIZE (1.91), BRD_COMP (1.59), BRD_EXP (1.45), CEO_DUAL (1.40) and GEN_DIV (1.21) are below 10 (Table 4), bringing the mean VIF value to 1.45. Furthermore, the result can be interpreted as no perfect linear relationship exist between two or more variables in the model. On another note, 1/VIF or tolerance shows us the level of collinearity of variables. An issue appears when the values of $1 / \mathrm{VIF}$ are lower than 0.1 , meaning that the variable can be in linear combination with other variables. All things considered, the tolerance coefficients for BRD_SIZE (0.52), BRD_COMP (0.62), BRD_EXP (0.68), CEO_DUAL (0.71) and GEN_DIV (0.82) have acceptable values and no multicollinearity among variables is detected.

Table 4. Multi-collinearity test between board characteristics variables

\begin{tabular}{c|c|c}
\hline Variable & VIF & $\mathbf{1 / V I F}$ \\
\hline BRD_SIZE & 1.91 & 0.524373 \\
BRD_COMP & 1.59 & 0.629670 \\
BRD_EXP & 1.45 & 0.688386 \\
CEO_DUAL & 1.40 & 0.714221 \\
GEN_DIV & 1.21 & 0.823916 \\
\hline Mean VIF & $\mathbf{1 . 4 5}$ & \\
\hline
\end{tabular}

Source: Authors calculations

The VIF values in the model are below 10 and in an acceptable range, therefore they indicate that the measures selected for assessing independent variables do not reach levels of multicollinearity. 


\section{CONCLUSION}

This research has yielded significant results in understanding and explaining the link between organizational and board attributes such as board experience, CEO duality, board size, board composition, and gender diversity on the financial performance of insurance companies in the Republic of North Macedonia. Results show that the board experience has a statistically significant (1\% level) and a positive impact on profitability. This confirms the hypotheses developed from the empirical and theoretical findings that as the number of highly qualified and experienced board members increases, the expertise and a wide variety of skills are obtained which better the decision-making process in an organization. Furthermore, the positive and statistically significant relationship between board composition and profitability at $10 \%$ level can be explained by the importance of an independent and competent board or the increased need of incorporating the expertise of independent and external members in the board that is a rare corporate practice, mostly defined within the supervisory board members and has limited influence to the forms' operative management practices and results. The negative effect of board size on insurers' profitability should be a matter of further analysis, as the companies do not appear with large boards. Regardless of the findings that larger boards tend to have a higher cost, we underline the issues of lack of coherence and openness, as well as lack of operational management practices that exist within the group and can lead to miscommunication and coordination issues as more influential for the structural distortion. Our findings are expected to challenge scholars in extending current literature and developing critical scientific discourse and motivate companies to emphasize the need and importance of corporate governance for the organizational growth, development, and market performance of the companies. The existing regulatory and supervisory regime of Solvency I, is preventing more substantial investment and evolution of the management bodies for the companies' change and transformation, thus prolonging the transformational qualitative influence at the general insurance industry. The expected implementation of the Solvency II regime is expected to exercise profound intervention and influence to the corporate governance by enhanced and advanced standards as key principles of good corporate governance. The established standards and criteria, in addition, should be imanently upgraded by the implementation of the valuable and effective factors such as Competence and Capacity, Innovation and Openness to Change, Sustainability and Long-term Orientation, Human rights, Cultural Diversity and Social Cohesion, that would be eventually matter of further scientific exploration by the authors.

Finally, the significance of the board characteristics would be additionaly emphisized during the burdened operational management of the insurance companies during the current 2020 pandemic year and especially in determining strategical change of the business and the insurance companies' internal adaptation to the external changes.

\section{REFERENCES}

Adam, R. B., and Mehran, H. (2003), "Is Corporate Governance Different for Bank Holding Companies?", Economic Policy Review - Federal Reserve Bank of New York, Vol. 9 No. 1, pp. 123-142.

Adams, R. B., and Ferreira, D. (2009), "Women in the boardroom and their impact on governance and performance". Journal of Financial Economics, Vol. 94 No.2, pp.291-309.

Agrawal, A., and Knoeber, C. (1996), "Firm Performance and Mechanisms to Control Agency Problems between Managers and Shareholders", Journal of Financial and Quantitative Analysis, Vol. 31 No. 3, pp. 377-397.

Al-Daoud, S. Z. Saidin, and S. Abidin (2016), "Board meeting and firm performance: Evidence from the Amman stock exchange. Corporate Board: Role, Duties and Composition", Vol. 12 No. 2, pp. 6-11. 
Andres P., Azofra, V. and Lopez, F. (2005), "Corporate boards in OECD countries: size, composition, functioning and effectiveness", Corporate Governance: an international review, Vol. 13 No. 2, pp. 197-210.

Arellano M. and Bond S., (1991), "Some Tests of Specification for Panel Data: Monte Carlo Evidence and an Application to Employment Equations", The Review of Economic Studies, Vol. 58 No. 2, pp. 277-297.

Awan, S.H. (2012), "Effect on board composition on firm performance: A case of Pakistan listed companies", Interdisciplinary Journal of Contemporary Research in Business, Vol. 3 No. 10, pp. 853-863.

Barnhart, S. W., Marr, M. W., and Rosenstein, S. (1994), "Firm Performance and Board Composition: Some New Evidence”, Managerial and Decision Economics, Vol. 15 No. 4, pp. 329-340

Bathala, C., and Rao, R. P. (1995), "The determinants of board composition: an agency theory perspective", Managerial and Decision Economics, Vol. 16, pp. 59-69.

Berger, A., Kick, T., and Schaeck, K. (2014), "Executive board composition and bank risk taking”, Journal of Corporate Finance, Vol. 28, pp. 48-65.

Bhagat, S. and Black, B. (2002), "The Non-Correlation between Board Independence and Long-Term Firm Performance”, Journal of Corporation Law, Vol. 27 No. 2, pp. 231-273.

Biggins, J. V. (1999), "Making Board Diversity Work", Corporate Board, Vol. 20 No. 117, pp. 11-17.

Blundell, R. and Bond, S. (1998), "Initial conditions and moment restrictions in dynamic panel data models", Journal of Econometrics, Vol. 87 No. 1, pp. 115-143.

Bonn, I. (2004), "Board Structure and Firm Performance: Evidence from Australia", Journal of the Australian and New Zealand Academy of Management, Vol. 10 No. 1, pp. 14-24.

Bonn, I., Yoshikawa, T., and Phan, Ph.H. (2004), "Effects of board structure on firm performance: A comparison of Japan and Australia", Asian Business and Management. Vol. 3 No. 1, pp. 105-125.

Campbell, K. and Vera, A. (2008), "Gender Diversity in the Boardroom and Firm Financial Performance”, Journal of Business Ethics, Vol. 83 No. 3, pp. 435-451.

Carlsson, R. H. (2001), "Ownership and Value Creation: Strategic Corporate Governance in the New Economy”, John Wiley \& Sons, Chichester, England.

Carpenter, M., and Westphal, J. (2000), "The Strategic Context Of External Network Ties: Examining The Impact Of Director Appointments On Board Involvement In Strategic Decision Making", Academy of Management Journal, Vol. 44 No.4, pp.639-660.

Chapple, L. and Humphrey, J. (2013), "Does Board Gender Diversity Have a Financial Impact? Evidence Using Stock Portfolio Performance", Journal of Business Ethics, Vol. 122 No. 4, pp. 709-723.

Chen, C. W., Barry Lin, J., and Yi, B. (2008), "CEO duality and firm performance-an endogenous issue", Corporate Ownership \& Control, Vol. 6 No. 1, pp. 58-65.

Cheng, S. (2008), "Board size and the variability of corporate performance", Journal of Financial Economics, Vol. 87 No. 1, pp. 157-176.

Coles, J. L., Daniel, N. D., and Naveen, L. (2008), "Boards: Does one size fit all”, Journal of Financial Economics, Vol. 87 No. 2, pp. 329-356.

Dahya, J., and McConnell, J. (2007), "Board Composition, Corporate Performance, and the Cadbury Committee Recommendation”, Journal of Financial and Quantitative Analysis, Vol. 42 No.3, pp. 535-564.

Dahya, J., and McConnell, J. J. (2005), Outside directors and corporate board decisions. Journal of Corporate Finance, Vol. 11 No. 1-2, pp. 37-60.

Daily C.M., and Dalton D.R. (1997), "CEO and Board Chair Roles Held Jointly or Separately: Much Ado about Nothing”, Academy of Management Executive, Vol. 11 No. 3, pp. 11-20. 
Daily, C. M., Certo, S. T., and Dalton, D. R. (1999), "A decade of corporate women: Some progress in the boardroom, none in the executive suite", Strategic Management Journal, Vol. 20 No. 1, pp. 93-100.

Dalton, D. R., Daily, C. M., Ellstrand, A. E. and Johnson, J. L., (1999), "Number of directors and financial performance. A meta-analysis", Academy of Management Journal, Vol. 42 No. 6, pp. 674- 686.

Dalton, D. R., Daily, C. M., Ellstrand, A. E. and Johnson, J. L., (1998), "Meta-analytic reviews of board composition, leadership structure, and financial performance", Strategic Management Journal, Vol. 19 No. 3, pp. 269-290.

Ding, D. K. and Charoenwong, Ch. (2004), "Women on Board: Is It Boon or Bane?", Financial Management Association European Conference, Research Collection Lee Kong Chian School Of Business, Zurich, April.

Dobbin F., and Jung J. (2011), "Corporate Board Gender Diversity and Stock Performance: The Competence Gap or Institutional Investor Bias?", North Carolina Law Review, Vol. 89 No. 3, pp. 809-838.

Doğan, M. (2013), "Does firm size affect the firm profitability? Evidence from Turkey", Research Journal of Financial Accounting, Vol. 4 No. 4, pp. 53-59.

Dowen, R.J. (1995), "Board of director quality and firm performance", International Journal of the Economics of Business, Vol. 2 No. 1, pp. 123-132.

D'Souza, F., Simkins, B. and Simpson, W. (2010). "The Gender and Ethnic Diversity of US Boards and Board Committees and Firm Financial Performance" Corporate Governance: An International Review. Vol. 18 No. 5, pp. 396-414.

Farrell, K. \& Hersch, Ph. (2005), "Additions to Corporate Boards: The Effect of Gender", Journal of Corporate Finance. Vol. 11 No. 1-2, pp. 85-106.

Gordini, N., and Rancati. E. (2017), "Gender diversity in the Italian boardroom and firm financial performance", Management Research Review, Vol. 40 No. 1, pp. 75-94.

Greenbury, R. (1995), “Report on Directors' Remuneration”, Gee Publishing, London.

Gujarati, D.N. (1995), "Basic Econometrics", 4th Edition, United State Military Academy, New York.

Hạnh, L., Ting, I. \& Kweh, Q.L., and Hoanh, L.T.H. (2018), "Board meeting frequency and financial performance: A case of listed firms in Vietnam", International Journal of Business and Society, Vol. 19 No. 2, pp. 464-472.

Haniffa, R.M., and T. E. Cooke (2002), "Culture, Corporate Governance and Disclosure in Malaysian Corporations", Abacus, Vol. 38 No. 3, pp. 317-349.

Hardwick, P., Adams, M. and Zou, H. (2004), "Corporate governance and cost efficiency in the United Kingdom life insurance industry", working paper.

Harris M., and Raviv A. (2008), "A Theory of Board Control and Size", The Review of Financial Studies, Vol. 21, No. 4, pp. 1797-1832

Hasnah K. (2009), "The impact of corporate governance and board performance on the performance of public listed companies in Malaysia”, Ph.D. Dissertation, University Sains Malaysia.

Hau, H., and Thum, M., (2009), "Subprime Crisis and Board (In-) Competence: Private vs. Public Banks in Germany", working paper series No. 2640, CESifo.

Hermalin, B. E., Weisbach, M. S., (1991), "The effects of board composition and direct incentives on firm performance", Financial Management, Vol. 20 No.4, pp. 101-112.

Higgs Report. (2003). Review of the role and effectiveness of non-executive directors. London: Department of trade and industry, HMSO.

Hung, Sh.W., Lu, W.M., Wang, W.K., Lu, E.T., (2012), "The effects of corporate governance on airline performance: Production and marketing efficiency perspectives", Transportation Research Part E: Logistics and Transportation Review, Vol 48 No.2, pp. 529-544. 
Hunt, S. D. (2000), A General Theory of Competition, Sage Publications, London.

Insurance Supervisory Agency (ISA), (2020), "Insurance market analysis in the Republic of Macedonia", available at: http://aso.mk/analiza/.

Insurance Supervisory Agency (ISA), (2020), Annual report of the insurance market in Republic of Macedonia, available at: http://aso.mk/en/category/reports/isa-reports/.

Isidro, H., and Sobral, M. (2014), "The Effects of Women on Corporate Boards on Firm Value, Financial Performance, and Ethical and Social Compliance", Journal of Business Ethics, Vol. 132 No.1, pp. 1-19.

Klein, A. (1998), "Firm Performance and Board Committee Structure", Journal of Law and Economics, Vol. 41 No.1, pp. 275-299.

Lasfer, M.A. (2004), "On the monitoring role of the board of directors: The case of the adoption of Cadbury recommendations in the UK", Advances in Financial Economics, Vol. 9, pp. 287326.

Lazzaretti, K., Kleinübing, G.C., Parodi, O.C.S. and Marcon, R. (2013), “Gender diversity in the boards of directors of Brazilian businesses", Gender in Management: An International Journal, Vol. 28 No. 2, pp. 94-110.

Leitao, N. C. (2010), "Financial Development and Economic Growth: A Panel Data Approach", Theoretical and Applied Economics, Vol. 10 No. 551, pp. 15-24

Limpaphayom, P., Sukchareonsin, S., (2003), "Board characteristics and firm performance: Evidence from Thailand", unpublished working paper, Sasin Graduate Institute of Business Administration of Chulalongkorn University, Thailand.

Lipton, M., and Lorsch, J. W. (1992), “A modest proposal for improved corporate governance", Business Lawyer, Vol. 48 No.1, pp. 59- 77.

Liu, H., and Fong, M.W. (2010), "Board characteristics of medium and large chinese companies", Corporate Governance: The international journal of business in society, Vol. 10 No. 2, pp.163-175.

Liu, Y., Wei, Z., and Xie, F. (2013), "Do Women Directors Improve Firm Performance in China?", Journal of Corporate Finance, Vol. 28, pp. 169-184.

Ljungquist U. (2007), "How do core competencies discriminate? Identification of influencing similarities and differences", The Journal of Corporate Transformation. Vol. 14, No. 4, pp. 237-247

Loderer, C., and U., Peyer, (2002), "Board Overlap, Seat Accumulation and Share Prices", European Financial Management, Vol. 8 No. 2, pp.165-92.

Low, D., Roberts, H. and Whiting, R. (2015), "Board gender diversity and firm performance: Empirical evidence from Hong Kong, South Korea, Malaysia and Singapore”, Pacific-Basin Finance Journal, Vol. 35, pp. 381-401.

Lückerath-Rovers, M. (2013), "Women on boards and firm performance", Journal of Management and Governence, Vol. 17 No. 2, pp. 491-509.

Mak, Y.T. and Y., Kusnadi, (2005), "Size Really Matters: Further Evidence on the Negative Relationship Between Board Size and Firm Value", Pacific - Basin Finance Journal, Vol. 13 No. 3, pp. 301-318.

Mehran, H. (1995), "Executive Compensation Structure, Ownership, and Firm Performance", Journal of Financial Economics, Vol. 38 No. 2, pp. 163-84.

Miller, T., and Triana, M.C. (2009), "Demographic diversity in the boardroom: mediators of the board diversity-firm performance relationship", Journal of Management Studies, Vol. 46 No.5, pp. 755-786.

Mohammadi, A., Basir, N.O. and Lööf, H. (2015), "CEO Duality and Firm Performance Revisited", working paper series in economics and institutions of innovation 400, Royal Institute of Technology, CESIS - Centre of Excellence for Science and Innovation Studies. 
Nguyen T. and Nguyen H. (2015), "Capital Structure and Firms' Performance: Evidence from Vietnam's Stock Exchange", International Journal of Economics and Finance, Vol. 7, No. 12. Ntim C.G. and Osei K.A., (2011), "The impact of Corporate board meetings on corporate performance in South Africa," African Review of Economics and Finance, Vol. 2, No. 2, pp. 83-103.

Pathan, Sh. and Faff, R., (2013), "Does board structure in banks really affect their performance?", Journal of Banking \& Finance, Elsevier, Vol.37 No.5, pp.1573-1589.

Peng, M. W., Zhang, S., and Li, X. (2007), "CEO duality and firm performance during China's institutional transitions", Management and Organization Review, Vol. 3 No. 2, pp. 205-225.

Prevost, A. K., Rao, R. P., and Hossain, M. (2002), "Board Composition in New Zealand: An Agency Perspective", Journal of Business Finance \& Accounting, Vol. 29 No. 6, pp. 731-760. Rechner, P. L., and Dalton, D. R. (1991), "CEO duality and organizational performance: a longitudinal analysis”, Strategic Management Journal, Vol. 12 No. 2, pp. 155-160.

Rosenstein, S., and Wyatt, J. G., (1990), "Outside directors, board independence, and shareholder wealth", Journal of Financial Economics Vol. 26 No. 2, pp. 175-191.

Shukeri S.N., Shin O.W., and Shaari M.S (2012), "Does Board of Director's Characteristics Affect Firm Performance? Evidence from Malaysian Public Listed Companies", International Business Research Archives Vol. 5 No. 9.

Singh, V. and Vinnicombe, S. (2004), "Why So Few Women Directors in Top UK Boardrooms? Evidence and Theoretical Explanations", Corporate Governance: An International Review, Vol. 12 No. 4, pp. 479-488.

Smith, N., Smith, V., and Verner, M. (2006), "Do Women in Top Management Affect Firm Performance? A Panel Study of 2,500 Danish Firms", International Journal of Productivity and Performance Management, Vol. 55 No. 5, pp. 569-593.

Torchia M., Calabrò A. and Huse M. (2011), "Women Directors on Corporate Boards: From Tokenism to Critical Mass", Journal of Business Ethics, Vol. 102 No. 2, pp. 299-317.

Torchia M., Calabrò A., and Morner M. (2015), "Board of directors' diversity, creativity, and cognitive conflict: the role of board members' interaction", International studies of management and organization. Vol. 45. No. 1, pp. 6-24.

Vafeas, N., (1999), "Board meeting frequency and firm performance", Journal of Financial Economics Vol. 53 No. 1, pp. 113-142.

Valenti, A., Luce, R. and Mayfield, C. (2011), "The effects of firm performance on corporate governance”, Management Research Review, Vol. 34 No. 3, pp. 266-283.

Vera, A. and Dornean, A. (2011), "Gender and management on Spanish SMEs: An empirical analysis", The International Journal of Human Resource Management. Vol. 12 No. 2, pp. 371388.

Yermack, D., (1996), "Higher market valuation of companies with a small board of directors", Journal of Financial Economics, Vol. 40 No. 2, pp. 185-211. 